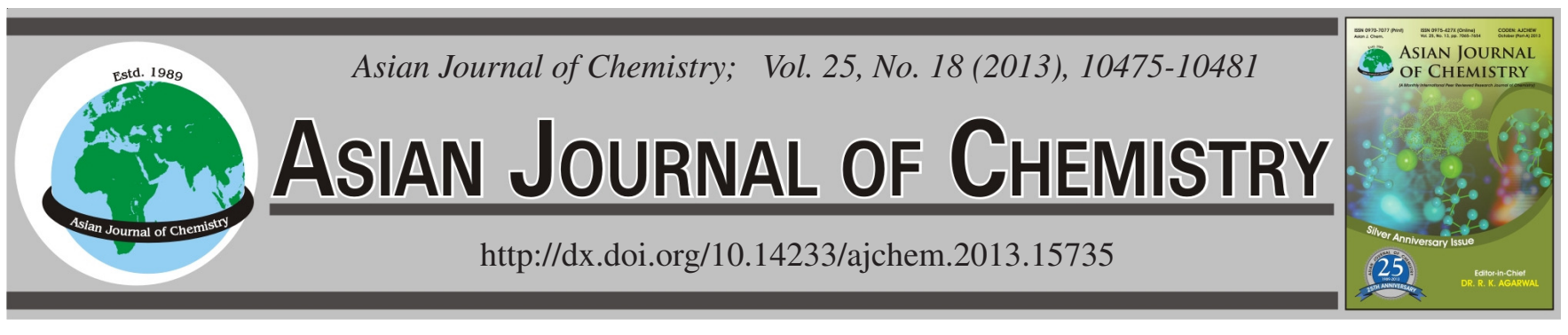

\title{
Synthesis and Spectroscopic Properties of Some Transition Metal Complexes with New Azo-Dyes Derived From Thiazole and Imidazole
}

\author{
Khalid J. Al-AdileE ${ }^{1, *}$, Khamis A. AbedalrazaQ ${ }^{2}$ and Zainab Mohsin Al-Hamdiny ${ }^{1}$
}

${ }^{1}$ Department of Chemistry, College of Science, University of AL-Qadisiya, Dewanyia 1753, Iraq

${ }^{2}$ Department of Chemistry, College of Education for Pure Scince, University of AL-Anbar, Ramadi, Iraq

*Corresponding author: E-mail: khalidke_1962@yahoo.com

\begin{abstract}
A new ligand containing thiazole and imidazole rings as organic heterocyclic azo dye compound 2-[-2-(6-nitro benzothiazolyl)azo]imidazole (NBTAI) was prepared by coupling reaction between 6-nitro benzothiazole chloride with imidazole in alkaline alcoholic solution. New six complexes with $\mathrm{Co}(\mathrm{II}), \mathrm{Ni}(\mathrm{II}), \mathrm{Cu}(\mathrm{II}), \mathrm{Zn}(\mathrm{II}), \mathrm{Cd}(\mathrm{II})$ and $\mathrm{Hg}$ (II) were prepared and characterized by elemental analysis, molar conductance measurements, magnetic moment measurements at room temperature, infrared and electronic spectra. The analytical data show that the metal to ligand ratio $[\mathrm{M}: \mathrm{L}]$ in all complexes is $(1: 2)$. The spectral and analytical data revealed that this ligand behaves as a bidentate chelating agent and the coordination number of all metal ions are found to be six in coordination through the nitrogen $\mathrm{N}_{3}$ atom of azo methine group of heterocyclic imidazole ring and the other nitrogen atom of azo group which is the farthest of imidazole molecule, from two ligands with two molecules and two chloride ions. The results are explained in the light of these analysis.
\end{abstract}

Key Words: Azo ligand, Coupling reaction, Metal complexes, Spectroscopic studies.

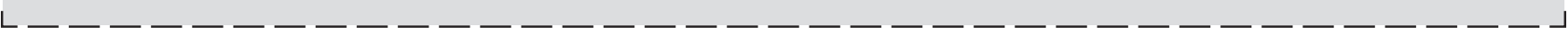

\section{INTRODUCTION}

The imidazole and thiazole derivatives characterized ligands azo dyes of heterocyclic compounds as highly effective against most of the elements of the periodic table as chemistry complexes. These ligands from a wide field of in practice. It is well know that for this type of compounds of the importance in the biological field due to presence of these compounds on different atoms such as oxygen, nitrogen and sulfur-qualify it for the link with the different elements and that small traces of these elements leads to inhibition of vitality activities ${ }^{1-3}$. Using to azo imidazole and thiazolyl azo in different fields have been used in medicine, science and technology, giving results are of great importance in the life $e^{4,5}$. That uses azo compounds depends on the chemical composition and method of application where generally used in dyeing processes $\operatorname{cotton}^{6}$, wool ${ }^{7}$, silk $^{8}$, rubber ${ }^{9}$, plastic ${ }^{10}$, print ${ }^{11}$ and in the fact that some drugs including discouraging the growth of germs ${ }^{12,13}$. An important uses of these compounds used analytical reagents ${ }^{14-16}$ for solvent extraction to determination of some metal ions. The azo imidazole and thiazolylazo compounds have important role in spectral determination field to determine the trance amount of elements especially transition metal ions because of high sensitivity and selectivity ${ }^{17-19}$. This class of azo dyes being a ( $\pi$-acidic) azo imine $(-\mathrm{N}=\mathrm{N}-\mathrm{C}=\mathrm{N}-)$ for this reason a number of these dyes were synthized and their abilities as chelating ligands ${ }^{20,21}$. In this work, the authors report the preparation and spectral identification of new ligand which contains two rings thiazole and imidazole (NBTAI) and its chelate complexes with $\mathrm{Co}(\mathrm{II}), \mathrm{Ni}$ (II), $\mathrm{Cu}(\mathrm{II}), \mathrm{Zn}$ (II), $\mathrm{Cd}$ (II) and $\mathrm{Hg}$ (II) metal ions.

\section{EXPERIMENTAL}

All chemical and solvents were purchased from Aldrich, Sigma, Fluka and B.D.H, except of 2-amino-6-nitro benzothiazole was prepared as described in the literature ${ }^{22}$. All chemical have been used without further purification and used as supplied by the companies. IR spectra were recorded as $\mathrm{KBr}$ discs using a Shimadzu 8400FTIR spectrophotometer in range (4000-400) $\mathrm{cm}^{-1}$. Electronic spectra of the prepared ligand and its complexes were measured in the region (200-1100) nm by using ethanol as solvent at $25^{\circ} \mathrm{C}$ using Shimadzu UV-visible. 1650 pc spectrophotometer, with $1.000 \pm 0.001 \mathrm{~cm}^{-1}$ match quartz cell. CHNS elemental analysis was performed on a Euro EA elemental analyzer (Al-Kufa University). The magnetic susceptibilities were measured on a MSB-Auto Magnetic Susceptibility Blance (Al-Nahrain University). Electrical conductivity measurements of the chelate complexes were recorded at room 
temperature in DMF $10^{-3} \mathrm{M}$ using a $31 \mathrm{~A}$ digital conductivity meter. The $\mathrm{pH}$ measurement were carried out using a Philips PW $9421 \mathrm{pH}$ meter \pm 0.001 and the melting points were determined on a Electro thermal melting point 9300 was used to measure the melting points of the ligand and their complexes. The metal contents of the complexes was measured by using atomic absorption by Shimadzu AA-160(Al-Kufa University). The chloride ion was estimated by mohr method ${ }^{23}$. Experiments and preparation of solutions and washing all glass ware using distilled water to twice in doubly distilled water.

Preparation of the azo dye ligand (NBTAI): The heterocyclic azo ligand (NBTAI) was prepared by the diazotization coupling reaction by following method proposed by Shibata et al. ${ }^{24}$ with some modifications (Scheme-I). 2-Amino-6-nitro benzothiazole ( $1.95 \mathrm{~g}, 0.01 \mathrm{~mol})$ was dissolved in mixture 30 $\mathrm{mL}$ distilled water and $5 \mathrm{~mL}$ of concentrated hydrochloric acid. The filtered solution was diazotized at $0-5{ }^{\circ} \mathrm{C}$ with $(0.84 \mathrm{~g}$, $0.012 \mathrm{~mol}$ ) sodium nitrite was dissolved in mixture $30 \mathrm{~mL}$ distilled water plus $15 \mathrm{~mL}$ of acetic acid-propionic acid mixture ( $15 \mathrm{~mL}$ acetic acid plus $5 \mathrm{~mL}$ of propionic acid), was added drop wise to solution of 2-amino-6-nitro benzothiazole and stirred for $25 \mathrm{~min}$ at $0-5{ }^{\circ} \mathrm{C}$ in ice-bath. The resulting diazonium chloride solution was added dropwise with cooling and stirring continuously at $0-5{ }^{\circ} \mathrm{C}$. The imidazole $(0.68 \mathrm{~g}$, $0.01 \mathrm{~mol}$ ) was dissolved in $150 \mathrm{~mL}$ of ethanol and $50 \mathrm{~mL}$ of $7 \%$ sodium hydroxide solution and $50 \mathrm{~mL}$ of $7 \%$ sodium carbonate solution were added. The mixture was stirred continuously for $3 \mathrm{~h}$ at $0-5{ }^{\circ} \mathrm{C}$ in ice-bath and allowed to stand overnight and concentrated (rotary evaporator). The precipitate was filtered and washed several times with cold distilled water until a negative chloride reaction with silver nitrate as well as washed with mixture distilled water and ethanol solution to remove the excess of unreacted substances. The product was finally recrystallized from $(1+1)$ aqueous ethanolic solution and dried in oven at $60^{\circ} \mathrm{C}$ for several hours and stored in a desiccator over anhydrous calcium chloride. The yield was $78 \%$ of orange powered. The purity was confirmed by the elemental analysis and TLC techniques.
Preparation of metal complexes: The metal complexes were prepared by adding $0.629 \mathrm{~g},(0.002 \mathrm{~mol})$ of ligand (NBTAI) dissolved in hot ethanol $(70 \mathrm{~mL})$ and added dropwise with stirring a stoichiometric amount of 1:2 [M:L] molar ratio (0.001 mol) for $\mathrm{Co}(\mathrm{II}), \mathrm{Ni}$ (II), $\mathrm{Cu}$ (II), $\mathrm{Zn}$ (II), $\mathrm{Cd}$ (II) and $\mathrm{Hg}$ (II) chloride salt dissolved in $40 \mathrm{~mL}$ hot buffer solution ammonium acetate at optimal $\mathrm{pH}$ for each metal ions. The reaction mixture was heated to $50-60{ }^{\circ} \mathrm{C}$ for $30-40 \mathrm{~min}$, until solid complexes were precipitated then left over night. The solid product thus formed was filtered off, washed distilled water until the solution become colourless and washed with $10 \mathrm{~mL}$ hot ethanol to remove any traces of the unreacted materials and dried in a desiccators over anhydrous $\mathrm{CaCl}_{2}$. Table- 1 shows the collects the physical properties and analytical data for the prepared ligand and their complexes.

\section{RESULTS AND DISCUSSION}

Characterization of azo dye ligand and its metal complexes: The azo dye ligand (NBTADI) was orange powder but the obtained complexes were found to be different colour crystals depending on the nature metal ion and stable in air at room temperature. The ligand and its chelate complexes were insoluble in water but soluble in most organic solvents such as ethanol, methanol, acetone, DMF and DMSO. The purity of azo dye complexes were tested by TLC technique and C.H.N.S elemental analysis.

Effect of pH: The effect of $\mathrm{pH}$ values for metal complex solutions was adjusted using dilute solutions $(0.1 \mathrm{M})$ of ammonium acetate, acetic acid and ammonia solution and the effect on absorbance was studied to determine the optimum $\mathrm{pH}$ in each case. The absorption of all chelate complexes solutions did not change over the whole range and very stable at $\mathrm{pH}=6-8$. The result are shown in Figs. 1 and 2 and maximum absorbance was obtained in $\mathrm{pH}$ range given in Table- 1 .

Effect of reaction time: The effect of time to get the complex is an important factor to obtain knowledge of the time period maintains the complex on stability especially employed in the field of analytical chemistry. The stabilizing complexes

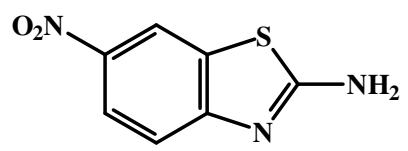

2-Amino-6-nitro benzothiazole distilled water + conc. $\mathrm{HCl}$

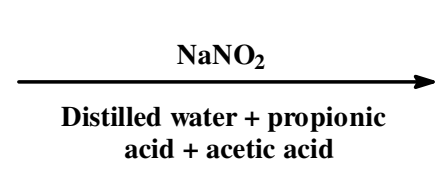

acid + acetic acid

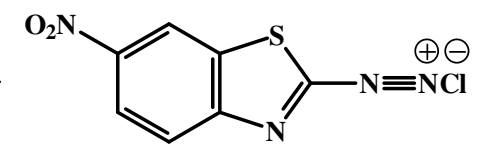

Diazonium salt

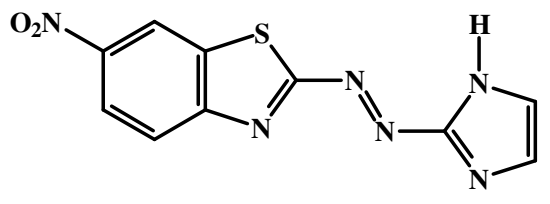

2-[2-(6Nitro benzothiazolyl)azo]imidazole (NBTAI)

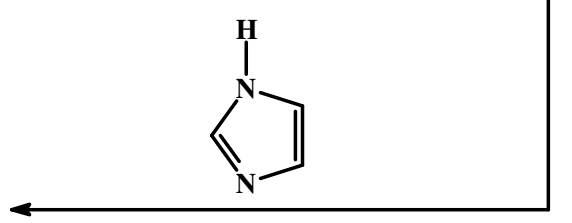

In ethanol, $\mathrm{pH}=\mathbf{6 . 0}$

$7 \% \mathrm{NaOH}+7 \% \mathrm{Na}_{2} \mathrm{CO}_{3}$

Scheme-I: Preparation of azo dye ligand2-[2-(6-nitro benzothiazolyl)azo]imidazole (NBTAI) 


\begin{tabular}{|c|c|c|c|c|c|c|c|c|c|c|}
\hline \multicolumn{11}{|c|}{$\begin{array}{c}\text { TABLE-1 } \\
\text { PHYSICAL PROPERTIES AND ELEMENTAL ANALYSIS FOR LIGAND (NBTAI) AND THEIR METAL COMPLEXES }\end{array}$} \\
\hline \multirow{2}{*}{ Compound } & \multirow{2}{*}{$\begin{array}{l}\text { m.p. } \\
\left({ }^{\circ} \mathrm{C}\right)\end{array}$} & \multirow{2}{*}{$\mathrm{pH}$} & \multirow{2}{*}{ Colour } & \multirow{2}{*}{$\begin{array}{c}\text { Yield } \\
(\%)\end{array}$} & \multirow{2}{*}{ m.f. (m.w.) } & \multicolumn{5}{|c|}{ Found Calc. (\%) } \\
\hline & & & & & & $\mathrm{C}$ & $\mathrm{H}$ & $\mathrm{N}$ & $\mathrm{S}$ & M \\
\hline $\mathrm{LH}=\mathrm{NBTAI}$ & 168 & 6.0 & Orange & 78 & $\begin{array}{c}\mathrm{C}_{10} \mathrm{H}_{6} \mathrm{~N}_{6} \mathrm{SO}_{2} \\
(274.25)\end{array}$ & $\begin{array}{c}43.61 \\
(43.79)\end{array}$ & $\begin{array}{l}2.15 \\
(2.21)\end{array}$ & $\begin{array}{c}30.72 \\
(30.64)\end{array}$ & $\begin{array}{c}11.52 \\
(11.69)\end{array}$ & - \\
\hline$\left[\mathrm{Co}(\mathrm{L})_{2} \mathrm{Cl}_{2}\right] \cdot \mathrm{H}_{2} \mathrm{O}$ & 201 & 7.5 & Green & 71 & $\begin{array}{l}\mathrm{C}_{20} \mathrm{H}_{14} \mathrm{~N}_{12} \mathrm{~S}_{2} \mathrm{O}_{5} \mathrm{Cl}_{2} \mathrm{Co} \\
(696.35)\end{array}$ & $\begin{array}{c}34.61 \\
(34.50)\end{array}$ & $\begin{array}{l}1.96 \\
(2.03)\end{array}$ & $\begin{array}{l}24.02 \\
(24.14)\end{array}$ & $\begin{array}{l}9.05 \\
(9.21)\end{array}$ & $\begin{array}{c}8.29 \\
(8.46)\end{array}$ \\
\hline$\left[\mathrm{Ni}(\mathrm{L})_{2} \mathrm{Cl}_{2}\right]$ & 187 & 7.0 & ireenish blue & 64 & $\begin{array}{c}\mathrm{C}_{20} \mathrm{H}_{14} \mathrm{~N}_{12} \mathrm{~S}_{2} \mathrm{O}_{5} \mathrm{Cl}_{2} \mathrm{Ni} \\
(678.12)\end{array}$ & $\begin{array}{c}35.24 \\
(35.42)\end{array}$ & $\begin{array}{c}1.72 \\
(1.78)\end{array}$ & $\begin{array}{l}24.61 \\
(24.79)\end{array}$ & $\begin{array}{c}9.26 \\
(9.45)\end{array}$ & $\begin{array}{c}8.47 \\
(8.66)\end{array}$ \\
\hline$\left[\mathrm{Cu}(\mathrm{L})_{2} \mathrm{Cl}_{2}\right] \cdot \mathrm{H}_{2} \mathrm{O}$ & 213 & 6.5 & Green & 76 & $\begin{array}{c}\mathrm{C}_{20} \mathrm{H}_{14} \mathrm{~N}_{12} \mathrm{~S}_{2} \mathrm{O}_{5} \mathrm{Cl}_{2} \mathrm{Cu} \\
(700.96)\end{array}$ & $\begin{array}{c}34.15 \\
(34.27)\end{array}$ & $\begin{array}{c}1.92 \\
(2.01)\end{array}$ & $\begin{array}{c}23.89 \\
(24.01)\end{array}$ & $\begin{array}{c}9.39 \\
(9.15)\end{array}$ & $\begin{array}{c}8.86 \\
(9.06)\end{array}$ \\
\hline$\left[\mathrm{Zn}(\mathrm{L})_{2} \mathrm{Cl}_{2}\right]$ & 192 & 7.0 & Purple & 57 & $\begin{array}{c}\mathrm{C}_{20} \mathrm{H}_{12} \mathrm{~N}_{12} \mathrm{~S}_{2} \mathrm{O}_{4} \mathrm{Cl}_{2} \mathrm{Zn} \\
(684.78)\end{array}$ & $\begin{array}{c}35.19 \\
(35.08)\end{array}$ & $\begin{array}{c}1.69 \\
(1.77)\end{array}$ & $\begin{array}{l}24.41 \\
(24.54)\end{array}$ & $\begin{array}{c}9.53 \\
(9.36)\end{array}$ & $\begin{array}{c}9.37 \\
(9.55)\end{array}$ \\
\hline$\left[\mathrm{Cd}(\mathrm{L})_{2} \mathrm{Cl}_{2}\right] \cdot \mathrm{H}_{2} \mathrm{O}$ & 203 & 6.0 & $\begin{array}{l}\text { Reddish } \\
\text { purple }\end{array}$ & 53 & $\begin{array}{c}\mathrm{C}_{20} \mathrm{H}_{14} \mathrm{~N}_{12} \mathrm{~S}_{2} \mathrm{O}_{5} \mathrm{Cl}_{2} \mathrm{Cd} \\
(749,82)\end{array}$ & $\begin{array}{c}32.13 \\
(32.04)\end{array}$ & $\begin{array}{c}1.83 \\
(1.88)\end{array}$ & $\begin{array}{l}22.56 \\
(22.42)\end{array}$ & $\begin{array}{c}8.76 \\
(8.55)\end{array}$ & - \\
\hline$\left[\mathrm{Hg}(\mathrm{L})_{2} \mathrm{Cl}_{2}\right] \cdot \mathrm{H}_{2} \mathrm{O}$ & 208 & 8.0 & Dark purple & 68 & $\begin{array}{c}\mathrm{C}_{20} \mathrm{H}_{14} \mathrm{~N}_{12} \mathrm{~S}_{2} \mathrm{O}_{5} \mathrm{Cl}_{2} \mathrm{Hg} \\
(838.01)\end{array}$ & $\begin{array}{c}28.48 \\
(28.66)\end{array}$ & $\begin{array}{c}1.61 \\
(1.68)\end{array}$ & $\begin{array}{l}20.19 \\
(20.06)\end{array}$ & $\begin{array}{c}7.88 \\
(7.65)\end{array}$ & - \\
\hline
\end{tabular}

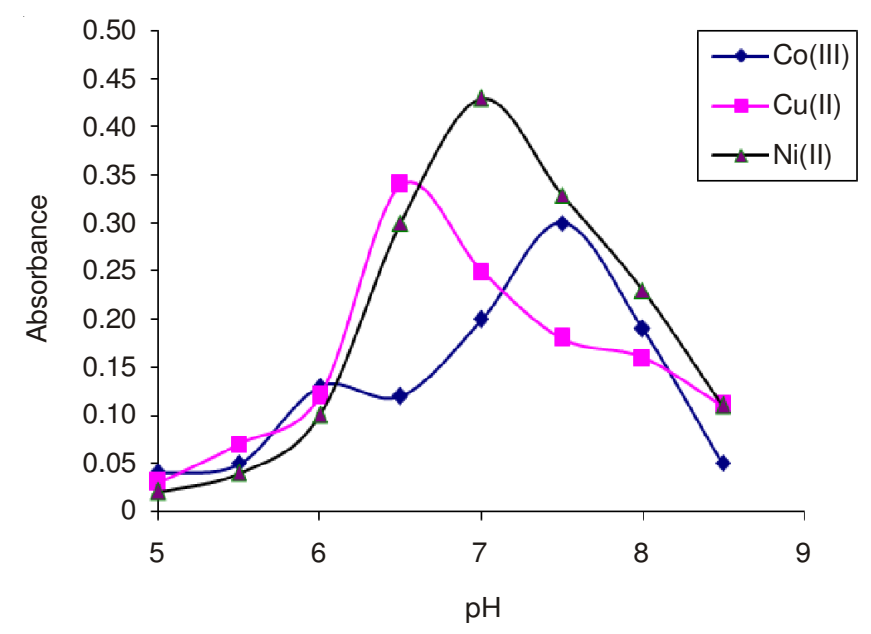

Fig. 1. Effect of $\mathrm{pH}$ on absorbance values of chelate complexes

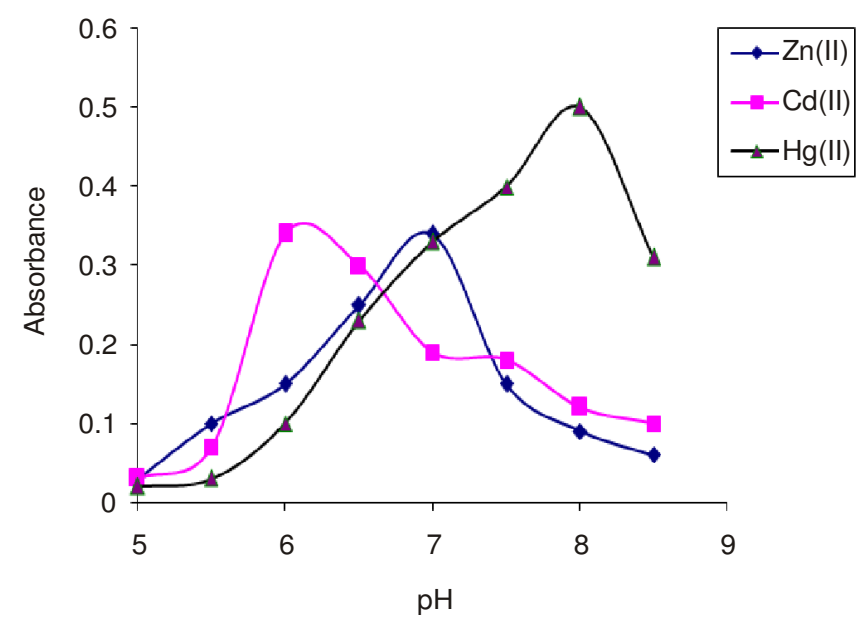

Fig. 2. Effect of $\mathrm{pH}$ on absorbance values of chelate complexes

prepared have been studied at the maximum wavelength absorption $\left(\lambda_{\max }\right)$ per complex by continue in the change at absorption for solutions complexes for a period of time ranged for the moment of the preparation of complex solution access to $180 \mathrm{~min}$. The results are described in the Figs. 3 and 4 indicate that the stability of solution of these complexes over time 10-15 min from the moment you start mixing which useful researcher in the field of spectral determination of metal ions ${ }^{25,26}$. The reaction complete in $5 \mathrm{~min}$ at room temperature and remains stable for at least $24 \mathrm{~h}$. This show the azo dye ligand (NBTAI) demonstrates strong coordination ligand with all metal ions.

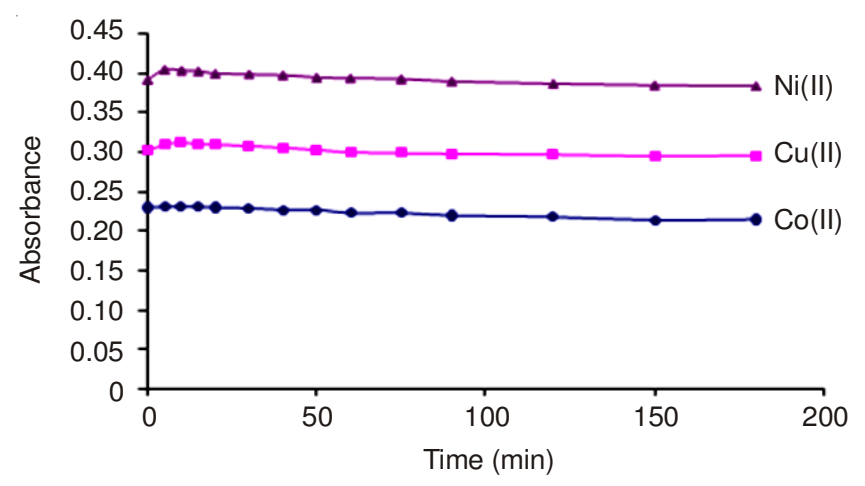

Fig. 3. Effect time on stability $\mathrm{Ni}(\mathrm{II}), \mathrm{Co}(\mathrm{III})$ and $\mathrm{Cu}(\mathrm{II})$-complexes

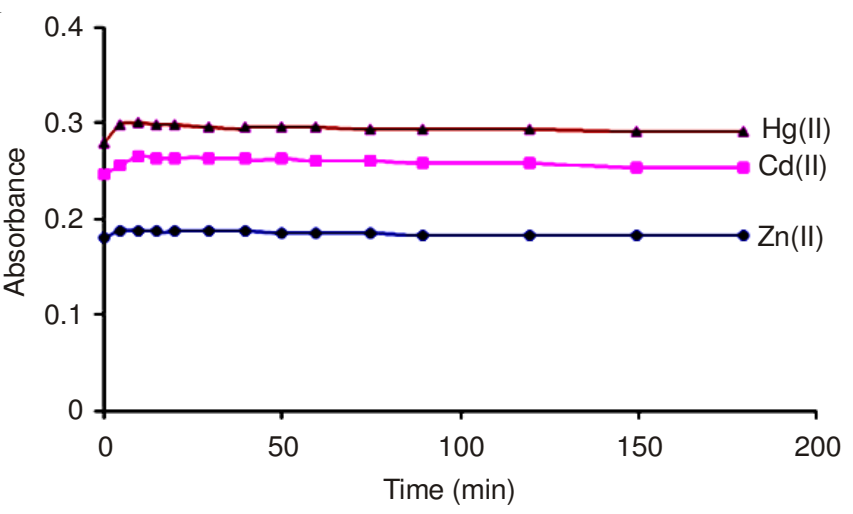

Fig. 4. Effect time on stability $\mathrm{Zn}(\mathrm{II}), \mathrm{Cd}(\mathrm{II})$ and $\mathrm{Hg}(\mathrm{II})$ )-complexes

Metal:ligand ratio: For the purpose of finding possible structural formula of prepared complexes was studied by molar ratio method at fixed optimum $\mathrm{pH}$ and concentration at wavelength maximum absorption $\left(\lambda_{\max }\right)$. The solutions of prepared 
complexes increase the intensity of the colours as approach point of intersection ratio (M:L) and color continous constant at passing this point which indicates that the complex formed in constant of solution ${ }^{25-28}$. A 1:2 [M:L] mole ratio suggested the formation of [M (NBAI)2] where $\mathrm{M}=\mathrm{Co}(\mathrm{II}), \mathrm{Ni}(\mathrm{II}), \mathrm{Cu}(\mathrm{II})$, $\mathrm{Zn}(\mathrm{II}), \mathrm{Cd}(\mathrm{II})$ and $\mathrm{Hg}(\mathrm{II})$.

Calculation of the metal complexes stability constant: The calculation of stability constants of complexes in their solutions depending on spectroscopic methods, particularly if colored complexes have taking advantage of the absorbance values obtained from calculations molar ratio of chelate complexes. The stability constants are obtained by measuring the absorbance of solution mixture of ligand and metal ion at fixed wavelength $\left(\lambda_{\max }\right)$ and optimum $\mathrm{pH}$ values. The degree of formation of the complexes is calculated according to the relation $\operatorname{ship}^{29}, \beta=\left(1-\alpha / 4 \alpha^{3} C^{2}\right), \alpha=($ Am-As/Am $)$, where As and Am are the absorbance of the partially and fully formed complexes respectively at optimum concentration. The calculated $\beta$ and $\log \beta$ values for prepared complexes are listed in Table- 2 . The stability constant follow the arrangement $\mathrm{Co}$ (II) $>\mathrm{Cu}$ (II) $>\mathrm{Ni}$ (II) $<\mathrm{Hg}$ (II) $<\mathrm{Cd}$ (II) $<\mathrm{Zn}$ (II) the sequence of metal ions of the first row transition metal agree with Irving-Williams series of stability constant ${ }^{30,36}$.

Molar conductivity measurements: The studied of molar conductivity of preapred chelat complexes solid solutions for ligand(NBTAI) were carried out in ethanol and DMF solvents $\left(10^{-3}\right) \mathrm{M}$ at room temperature. The results proved in the Table-2 this study has shown the values of molar conductivity of all metal complexes that non-electrolyte and no conductive species exist ${ }^{26,31-33}$.

Infrared spectra: The infrared absorption of the ligand its complexes ( $\mathrm{KBr}$ disc) have been studied and given in Table- 3 . The comparison between spectra of ligand with the coordination complexes have revealed certain characteristic differences. The IR spectrum of free ligand (NBTADI) shows a weak and broad band around $3437 \mathrm{~cm}^{-1}$ due to the $v(\mathrm{~N}-\mathrm{H})$ of imidazole ring $^{33,34}$. This band remains in the same region in ligand and in solid chelate complexes spectra. Thus the remaining of the hydrogen of (N-H) group indicates non involvement in coordination of the ligand to the metal ions ${ }^{35}$. IR spectra of $\mathrm{Co}(\mathrm{II})$, $\mathrm{Cu}(\mathrm{II}), \mathrm{Cd}(\mathrm{II})$ and $\mathrm{Hg}(\mathrm{II})$ metal complexes exhibit a broad in the range of $3332-3280 \mathrm{~cm}^{-1}$ due to presence of water molecules $^{36}$. Two weak absorption bands had been observed at 3085 $\mathrm{cm}^{-1}$ and $2970 \mathrm{~cm}^{-1}$ in ligand specterum which are due to $v(\mathrm{C}-\mathrm{H})$ aromatic and aliphatic respectively. These bands are stable in postion and intensity for both free ligand and metal complexes. The ligand shows two absorption bands at 1615 $\mathrm{cm}^{-1}$ and $1518 \mathrm{~cm}^{-1}$ due to $v(\mathrm{C}=\mathrm{N})$ of thiazole and imidazole rings ${ }^{31-33}$. In the spectra of metal complexes it is observed with alittle change in shape and shifted to lower frequencies at 1517$1490 \mathrm{~cm}^{-1}$ attributable $v(\mathrm{C}=\mathrm{N})$ of imidazole ring ${ }^{33}$. while the remaining absorption band $v(\mathrm{C}=\mathrm{N})$ attributable to thiazole ring is stable in position and unchanged in all metal complexes which means it dose not coordination the metal ion with nitrogen of thiazole ring ${ }^{24}$. One absorption band is observed at 1459 $\mathrm{cm}^{-1}$ in free ligand spectrum is assigned to the existence of $v(\mathrm{~N}=\mathrm{N})$ azo group while in chelate complexes spectra these bands are shifted to lower frequencies at $1435-1415 \mathrm{~cm}^{-1}$ with decreased or increased intensity.

The changing of position and intensity of this absorption band (azo group) indicates the effected of this group and by complexation ${ }^{37}$. Another bands appeared at 1335 and $840 \mathrm{~cm}^{-1}$ in the free ligand spectrum. These bands are due to $\mathrm{v}(\mathrm{C}-\mathrm{S})$ of the thiazole ring ${ }^{31-33,38}$. The existence of these bands in all metal complexes means that the sulphur atom of the thiazole ring does not participate in coordination ${ }^{1,28,31,33}$. New absorption in the range of $520-447 \mathrm{~cm}^{-1}$ which are not present in the spectrum of free ligand are due to $v(M-N)$ band vibration ${ }^{39}$. IR spectra data lead to suggest that the ligand behaves as a bidentate chelating agent coordinating through the nitrogen atom of azo group nearest to thiazole ring and $\mathrm{N}_{3}$ atom of imidazole ring to give five membered chelate ring. Some representative spectra are given in Fig. 5-7.

Electronic spectra and magnetic moments: The electronic spectra of ligand and their metal complexes were studied in absolute ethanol as a solvent. The spectral data and magnetic moments are listed in Table-4 and Fig. 8-11. The free ligand (NBTAI) spectrum gives three absorption bands were detected

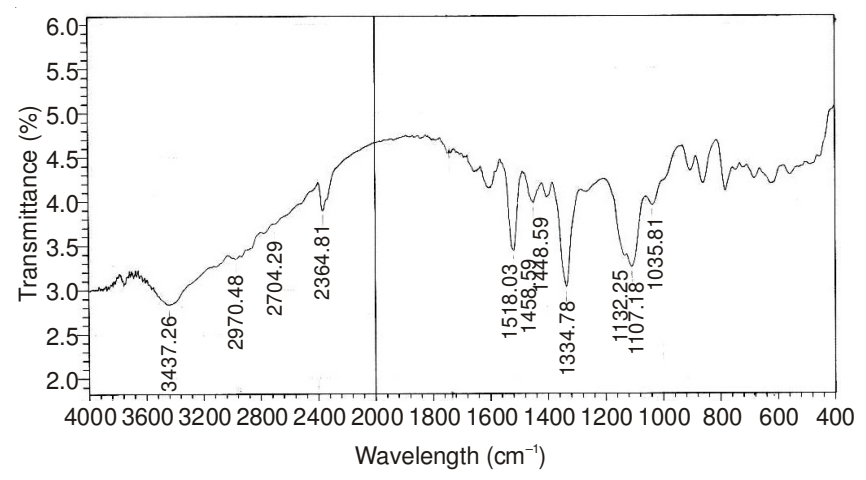

Fig. 5. IR spectrum of ligand (NBTAI)

TABLE-2

STABILITY CONSTANT VALUES ( $\beta$ AND $\log \beta$ ), MOLAR CONDUCTIVITY, OPTIMAL CONCENTRATION, MAXIMUM WAVELENGTH $\left(\lambda_{\max }\right)$ AND MOLAR ABSORPTIVITY $(\varepsilon)$ OF CHELATE COMPLEXES

\begin{tabular}{|c|c|c|c|c|c|c|c|c|}
\hline \multirow{2}{*}{$\begin{array}{c}\text { Ligand } \\
(\text { Conc. }=1.75 \\
\left.\times 10^{-4} \mathrm{M}\right)\end{array}$} & \multirow[t]{2}{*}{ Metal ion } & \multirow{2}{*}{$\begin{array}{l}\text { Optimal molar } \\
\text { conc. } \times 10^{-4} \mathrm{M}\end{array}$} & \multirow{2}{*}{$\begin{array}{l}\text { Optimal wave } \\
\text { length } \lambda_{\max }(\mathrm{nm})\end{array}$} & \multirow{2}{*}{$\begin{array}{l}\text { Molar absorptivity } \\
(\varepsilon) \times 10^{3} \mathrm{~L} \mathrm{~mol}^{-1} \mathrm{~cm}^{-1}\end{array}$} & \multicolumn{2}{|c|}{$\begin{array}{l}\text { Molar conductivity } \\
\left(\mathrm{S} \mathrm{cm}^{2} \mathrm{~mol}^{-1}\right)\end{array}$} & \multirow{2}{*}{$\begin{array}{l}\text { Stability constant } \\
\text { ( } \beta)\left(\mathrm{L}^{2} \mathrm{~mol}^{-2}\right)\end{array}$} & \multirow[t]{2}{*}{$\log \beta$} \\
\hline & & & & & $\mathrm{EtOH}$ & DMF & & \\
\hline \multirow{6}{*}{$\begin{array}{c}\mathrm{LH}=\mathrm{NBTAI} \\
\lambda_{\max }=397 \mathrm{~nm} \\
\varepsilon=8.16 \times 10^{3} \\
\mathrm{~L} \mathrm{~mol}^{-1} \mathrm{~cm}^{-1}\end{array}$} & $\mathrm{Co}(\mathrm{II})$ & 1.5 & 629 & 1.67 & 7.83 & 9.65 & $1.22 \times 10^{12}$ & 12.08 \\
\hline & $\mathrm{Ni}(\mathrm{II})$ & 1.75 & 636 & 3.26 & 8.47 & 10.41 & $3.51 \times 10^{10}$ & 10.54 \\
\hline & $\mathrm{Cu}(\mathrm{II})$ & 2.00 & 623 & 2.63 & 7.52 & 9.18 & $7.45 \times 10^{1^{0}}$ & 10.87 \\
\hline & $\mathrm{Zn}$ (II) & 1.50 & 521 & 2.52 & 7.14 & 8.53 & $2.00 \times 10^{7}$ & 7.30 \\
\hline & $\mathrm{Cd}(\mathrm{II})$ & 1.50 & 518 & 2.06 & 6.49 & 7.09 & $7.20 \times 10^{7}$ & 7.85 \\
\hline & $\mathrm{Hg}$ (II) & 2.25 & 537 & 1.83 & 6.18 & 8.26 & $4.05 \times 10^{8}$ & 8.60 \\
\hline
\end{tabular}




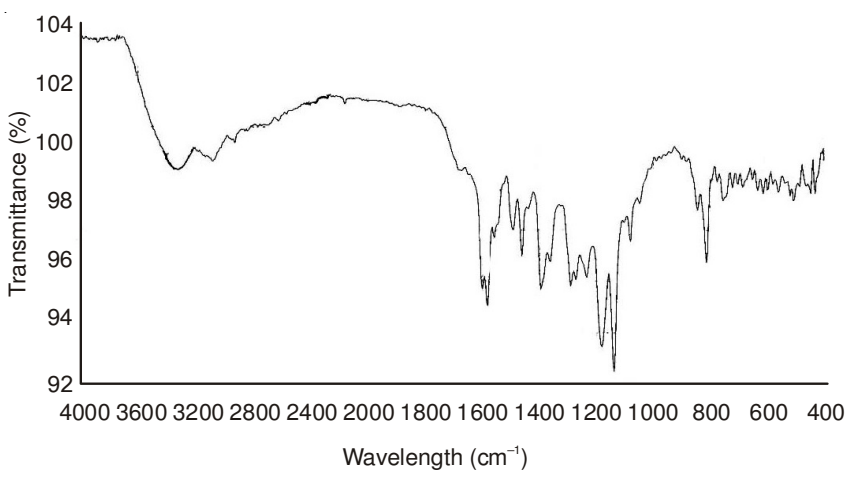

Fig. 6. IR spectrum of Co(III)-complex

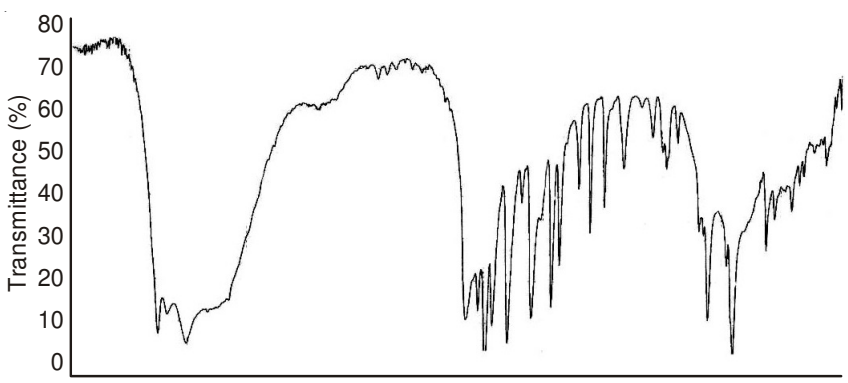

Fig. 7. IR spectrum of $\mathrm{Hg}$ (II)-Complex

first band located at $387 \mathrm{~nm}\left(25840 \mathrm{~cm}^{-1}\right)$ for $\left(\mathrm{n} \rightarrow \pi^{*}\right)$ transition of the azo group $(\mathrm{N}=\mathrm{N})$, this band showed a red shift on coordination with a metal ion. The second band observed at $291 \mathrm{~nm}$ $\left(34364 \mathrm{~cm}^{-1}\right)$ due to $\left(\pi \rightarrow \pi^{*}\right)$ transition to the $(\mathrm{C}=\mathrm{C})$ group in heterocyclic imidazole and thiazole rings ${ }^{26,31,33,40}$. while the third band at $263 \mathrm{~nm}(38023) \mathrm{cm}^{-1}$ for $\left(\mathrm{n} \rightarrow \sigma^{*}\right)$ transition with in heterocyclic imidazole and thiazole rings .

Cobalt(II)-complex: The electronic spectrum of Co(II)complex was studied in $10^{-3} \mathrm{M}$ ethanolic solution shows three absorption bands at $974 \mathrm{~nm}\left(10235 \mathrm{~cm}^{-1}\right), 629 \mathrm{~nm}\left(15898 \mathrm{~cm}^{-1}\right)$ and $350 \mathrm{~nm}\left(26571 \mathrm{~cm}^{-1}\right)$ these are assigned to ${ }^{4} \mathrm{~T}_{\mathrm{lg}(\mathrm{F})} \rightarrow{ }^{4} \mathrm{~T}_{2 \mathrm{~g}(\mathrm{~F})}$ $\left(v_{1}\right),{ }^{4} \mathrm{~T}_{\lg (\mathrm{F})} \rightarrow{ }^{4} \mathrm{~A}_{2 \mathrm{~g}(\mathrm{~F})}\left(\mathrm{V}_{2}\right)$ and ${ }^{4} \mathrm{~T}_{\lg (\mathrm{F})} \rightarrow{ }^{4} \mathrm{~T}_{\lg (\mathrm{p})}\left(\mathrm{V}_{3}\right)$ transition, respectively. The magnatic moment of the this complex has been found to be 5.07 B.M which correspond to three unpaired electrons which may suggest an distorted octahedral structure (Z-out) and hybridization $s p^{3} d^{2}\left({ }^{5} \mathrm{t}_{2 \mathrm{~g}}{ }^{2} \mathrm{e}_{\mathrm{g}}\right)^{41}$.
Nickel(II)-complex: The electronic spectrum of this complex show three absorption bands in $\left(10^{-3}\right) \mathrm{M}$ ethanolic solution at $977 \mathrm{~nm}\left(10235 \mathrm{~cm}^{-1}\right), 636 \mathrm{~nm}\left(15723 \mathrm{~cm}^{-1}\right)$, which suggesting the existence of ${ }^{3} \mathrm{~A}_{2 \mathrm{~g}} \rightarrow{ }^{3} \mathrm{~T}_{2 \mathrm{~g}(\mathrm{~F})}\left(\mathrm{V}_{1}\right),{ }^{3} \mathrm{~A}_{2 \mathrm{~g}} \rightarrow{ }^{3} \mathrm{~T}_{1 \mathrm{~g}(\mathrm{~F})}\left(\mathrm{V}_{2}\right)$ and ${ }^{3} \mathrm{~A}_{2 \mathrm{~g}} \rightarrow{ }^{3} \mathrm{~T}_{\mathrm{gg}(\mathrm{p})}\left(\mathrm{V}_{3}\right)$ transition respectively. For the Ni(II)-complex the value of magnetic moment was found to be 3.18 B.M. because of presence of two unpaired electrons which may suggests high spin a regular octahedral geometry ${ }^{42}\left({ }^{6} \mathrm{t}_{2 \mathrm{~g}}{ }^{2} \mathrm{e}_{\mathrm{g}}\right)$ and hybridization $s p^{3} d^{2}$.

Copper(II)-complex: The electronic absorption spectrum of $\mathrm{Cu}$ (II)-complex shows a broad band around at $623 \mathrm{~nm}$ $\left(16051 \mathrm{~cm}^{-1}\right)$ in $\left(10^{-3}\right) \mathrm{M}$ ethanolic solution due to ${ }^{2} \mathrm{E}_{\mathrm{g}} \rightarrow{ }^{2} \mathrm{~T}_{2 \mathrm{~g}}$

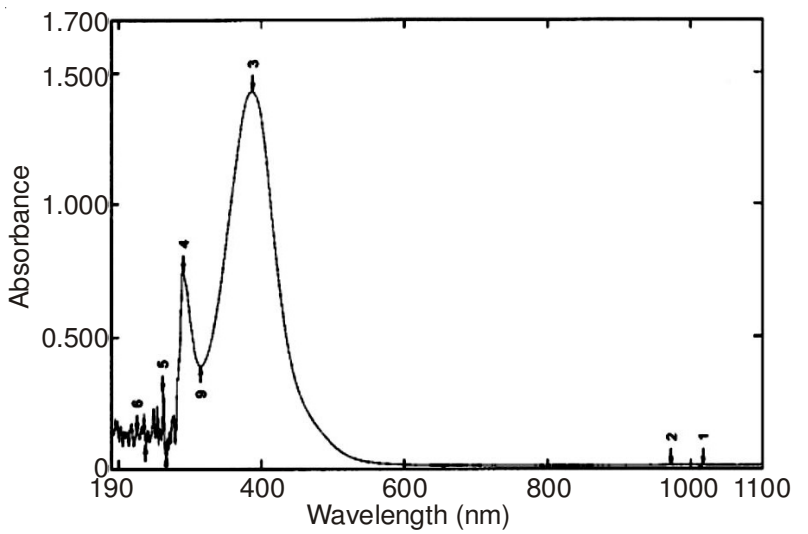

Fig. 8. UV-visible spectrum of ligand(NBTAI)

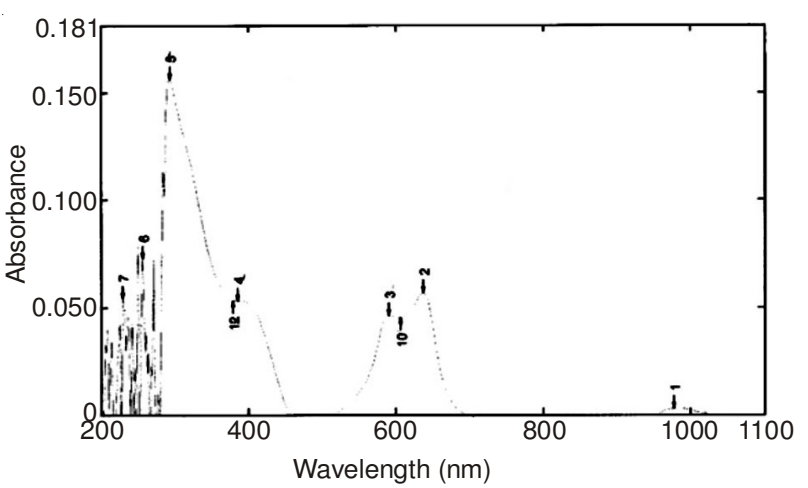

Fig. 9. UV-visible spectrum of Ni(II)-Complex

TABLE-3

KEY IR ABSORPTION BANDS $\left(\mathrm{cm}^{-1}\right)$ OF THE AZO DYE LIGAND (NBTAI) AND ITS METAL COMPLEXES

\begin{tabular}{|c|c|c|c|c|c|c|c|c|c|c|}
\hline Compound & $v(\mathrm{~N}-\mathrm{H})$ & $v(\mathrm{O}-\mathrm{H})$ & $\begin{array}{c}\mathrm{v}(\mathrm{C}=\mathrm{N}) \\
\text { imidazolee }\end{array}$ & $\begin{array}{l}v(\mathrm{C}=\mathrm{N}) \\
\text { thiazole }\end{array}$ & $v(\mathrm{~N}=\mathrm{N})$ & $v(\mathrm{C}=\mathrm{C})$ & $v(\mathrm{C}-\mathrm{N}=\mathrm{N}-\mathrm{C})$ & $\begin{array}{l}v(\mathrm{C}-\mathrm{S}) \\
\text { thiazole }\end{array}$ & $\begin{array}{l}v(\mathrm{C}-\mathrm{N}) \text { thia. } \\
v(\mathrm{C}-\mathrm{N}) \text { imid. }\end{array}$ & $v(\mathrm{M}-\mathrm{N})$ \\
\hline $\mathrm{LH}=\mathrm{NBTAI}$ & $\begin{array}{c}3437 w \\
\text { br. }\end{array}$ & - & $1615 \mathrm{~m}$ & $1518 \mathrm{~s}$. & $1459 \mathrm{~m}$ & $1335 \mathrm{~s}$. & $1245 w$. & $\begin{array}{l}1132 \mathrm{w} . \\
867 \mathrm{~m} .\end{array}$ & $\begin{array}{c}1107 \mathrm{~m}, \mathrm{sh} . \\
775 \mathrm{~m} .\end{array}$ & - \\
\hline$\left[\mathrm{Co}(\mathrm{L})_{2} \mathrm{Cl}_{2}\right] \cdot \mathrm{H}_{2} \mathrm{O}$ & $\begin{array}{c}3427 w \\
\text { br. }\end{array}$ & $\begin{array}{c}3420 w \\
\text { br. }\end{array}$ & $\begin{array}{c}1590 \mathrm{~m}, \\
\text { br. }\end{array}$ & $1515 \mathrm{~m}$ & $1440 \mathrm{~m}$. & $1400 \mathrm{~m}, \mathrm{~h}$ & $1255 w$. & $\begin{array}{l}1185 \mathrm{~s} . \\
860 \mathrm{~m} .\end{array}$ & $\begin{array}{l}1120 \mathrm{~s} . \\
835 \mathrm{~m} .\end{array}$ & $515 \mathrm{w}$. \\
\hline$\left[\mathrm{Ni}(\mathrm{L})_{2} \mathrm{Cl}_{2}\right]$ & $\begin{array}{c}3418 w, \\
\text { br. }\end{array}$ & - & $1589 \mathrm{~m}$. & 1519vs. & 1448w. & 1342vs. & $1240 \mathrm{w}, \mathrm{sh}$. & $\begin{array}{l}1140 w, b r \\
856 m .\end{array}$ & $\begin{array}{c}1103 \mathrm{~m}, \mathrm{sh} . \\
780 \mathrm{~m} .\end{array}$ & 510w. \\
\hline$\left[\mathrm{Cu}(\mathrm{L})_{2} \mathrm{Cl}_{2}\right] \cdot \mathrm{H}_{2} \mathrm{O}$ & $3394 \mathrm{~m}$. & $\begin{array}{c}3332 w \\
\text { br. }\end{array}$ & $1658 \mathrm{~m}$. & $1512 \mathrm{~m}$ & $1434 \mathrm{~m}$ & $1342 \mathrm{~m}$. & $1265 w$. & $\begin{array}{l}1242 \mathrm{~m} . \\
841 \mathrm{~m} .\end{array}$ & $\begin{array}{c}987 \mathrm{~m} . \\
756 \mathrm{~s} .\end{array}$ & $447 w$. \\
\hline$\left[\mathrm{Zn}(\mathrm{L})_{2} \mathrm{Cl}_{2}\right]$ & 3440 & - & $1595 \mathrm{~m}$. & $1520 \mathrm{~s}$. & $1432 \mathrm{~m}$ & 1378s. & $1245 \mathrm{~m} . \mathrm{sh}$. & $\begin{array}{l}1128 \mathrm{~m} . \\
853 \mathrm{~m} .\end{array}$ & $\begin{array}{c}1109 \mathrm{~m} . \\
812 \mathrm{~s} .\end{array}$ & $520 \mathrm{w}$. \\
\hline$\left[\mathrm{Cd}(\mathrm{L})_{2} \mathrm{Cl}_{2}\right] \cdot \mathrm{H}_{2} \mathrm{O}$ & 3432 & $\begin{array}{c}3417 \text { w. } \\
\text { br. }\end{array}$ & $1593 \mathrm{~m}$ & $1523 \mathrm{~s}$. & $1421 \mathrm{~m}$ & $1337 \mathrm{~m}$ & $1240 \mathrm{~m} . \mathrm{sh}$. & $\begin{array}{l}1130 \mathrm{~m} . \\
847 \mathrm{~m} .\end{array}$ & $\begin{array}{c}1115 \mathrm{~m}, \mathrm{sh} . \\
765 \mathrm{~m} .\end{array}$ & 495w. \\
\hline$\left[\mathrm{Hg}(\mathrm{L})_{2} \mathrm{Cl}_{2}\right] \cdot \mathrm{H}_{2} \mathrm{O}$ & 3448 & $\begin{array}{c}3360 w . \\
\text { br. }\end{array}$ & 1610v.s. & 1520vs. & $1445 v s$ & $1348 \mathrm{~m}$ & 1260vs. & $\begin{array}{l}1238 \mathrm{~m} \\
8845 \mathrm{~s} .\end{array}$ & $\begin{array}{c}985 \mathrm{~m}, \mathrm{sh} . \\
760 \mathrm{~s} .\end{array}$ & 480w. \\
\hline
\end{tabular}




\begin{tabular}{|c|c|c|c|c|c|c|}
\hline \multicolumn{7}{|c|}{$\begin{array}{c}\text { TABLE-4 } \\
\text { ELECTRONIC SPECTRA, MAGNETIC MOMENTS, GEOMETRY AND HYBRIDIZATION }\end{array}$} \\
\hline Complexes & $\lambda_{\max }(\mathrm{nm})$ & Absorption bands $\left(\mathrm{cm}^{-1}\right)$ & Transition & $\mu_{\text {eff }}($ B.M $)$ & Geometry & Hybrdization \\
\hline \multirow{3}{*}{$\begin{array}{l}\text { LH }=\text { ligand } \\
(\text { NBTAI })\end{array}$} & 387 & 25840 & $\mathrm{n} \rightarrow \pi^{*}$ & \multirow{3}{*}{-} & \multirow{3}{*}{-} & \multirow{3}{*}{-} \\
\hline & 291 & 34364 & $\pi \rightarrow \pi^{*}$ & & & \\
\hline & 263 & 38023 & $\mathrm{n} \rightarrow \sigma^{*}$ & & & \\
\hline \multirow{4}{*}[\mathrm{Co}(\mathrm{L})_{2}\mathrm{Cl}_{2}]{$\cdot \mathrm{H}_{2} \mathrm{O}$} & 974 & 10267 & ${ }^{4} \mathrm{~T}_{1} \mathrm{~g}_{(\mathrm{F})} \rightarrow{ }^{4} \mathrm{~T}_{2} \mathrm{~g}_{(\mathrm{F})}\left(\mathrm{v}_{1}\right)$ & \multirow{4}{*}{5.02} & \multirow{4}{*}{$\begin{array}{l}\text { Octahedral } \\
\text { (distorted, Z-out) }\end{array}$} & \multirow{4}{*}{$\mathrm{sp}^{3} \mathrm{~d}^{2}$ (high spin) } \\
\hline & 629 & 15898 & ${ }^{4} \mathrm{~T}_{1} \mathrm{~g}_{(\mathrm{F})} \rightarrow{ }^{4} \mathrm{~A}_{2} \mathrm{~g}_{(\mathrm{F})}\left(\mathrm{v}_{2}\right)$ & & & \\
\hline & 350 & 26571 & ${ }^{4} \mathrm{~T}_{1} \mathrm{~g}_{(\mathrm{F})} \rightarrow{ }^{4} \mathrm{~T}_{1} \mathrm{~g}_{(\mathrm{p})}\left(\mathrm{v}_{3}\right)$ & & & \\
\hline & 977 & 10235 & ${ }^{3} \mathrm{~A}_{2} \mathrm{~g}_{(\mathrm{F})} \rightarrow{ }^{3} \mathrm{~T}_{2} \mathrm{~g}_{(\mathrm{F})}\left(\mathrm{v}_{1}\right)$ & & & \\
\hline \multirow[t]{2}{*}[\mathrm{Ni}(\mathrm{L})_{2}\mathrm{Cl}_{2}]{} & 636 & 15723 & ${ }^{3} \mathrm{~A}_{2} \mathrm{~g}_{(\mathrm{F})} \rightarrow{ }^{3} \mathrm{~T}_{1} \mathrm{~g}_{(\mathrm{F})}\left(\mathrm{V}_{2}\right)$ & \multirow[t]{2}{*}{3.18} & Octahedral & \multirow{2}{*}{$\mathrm{sp}^{3} \mathrm{~d}^{2}$ (high spin) } \\
\hline & 589 & 16978 & ${ }^{3} \mathrm{~A}_{2} \mathrm{~g}_{(\mathrm{F})} \rightarrow{ }^{3} \mathrm{~T}_{1} \mathrm{~g}_{(\mathrm{P})}\left(\mathrm{v}_{2}\right)$ & & (regular) & \\
\hline$\left[\mathrm{Cu}(\mathrm{L})_{2} \mathrm{Cl}_{2}\right] \cdot \mathrm{H}_{2} \mathrm{O}$ & 623 & 16051 & ${ }^{2} \mathrm{Eg} \rightarrow{ }^{2} \mathrm{~T}_{2} \mathrm{~g}$ & 1.64 & $\begin{array}{l}\text { Octahedral } \\
\text { (distorted,Z-out or Z-ir }\end{array}$ & $\mathrm{sp}^{3} \mathrm{~d}^{2}$ \\
\hline$\left[\mathrm{Zn}(\mathrm{L})_{2} \mathrm{Cl}_{2}\right]$ & 521 & 15194 & $\mathrm{M} \rightarrow \mathrm{L}, \mathrm{CT}$ & dia & Octahedral (regular) & $\mathrm{sp}^{3} \mathrm{~d}^{2}$ \\
\hline$\left[\mathrm{Cd}(\mathrm{L})_{2} \mathrm{Cl}_{2}\right] \cdot \mathrm{H}_{2} \mathrm{O}$ & 518 & 15305 & $\mathrm{M} \rightarrow \mathrm{L}, \mathrm{CT}$ & dia & Octahedral (regular) & $\mathrm{sp}^{3} \mathrm{~d}^{2}$ \\
\hline$\left[\mathrm{Hg}(\mathrm{L})_{2} \mathrm{Cl}_{2}\right] \cdot \mathrm{H}_{2} \mathrm{O}$ & 537 & 16622 & $\mathrm{M} \rightarrow \mathrm{L}, \mathrm{CT}$ & dia & Octahedral (regular) & $\mathrm{sp}^{3} \mathrm{~d}^{2}$ \\
\hline
\end{tabular}

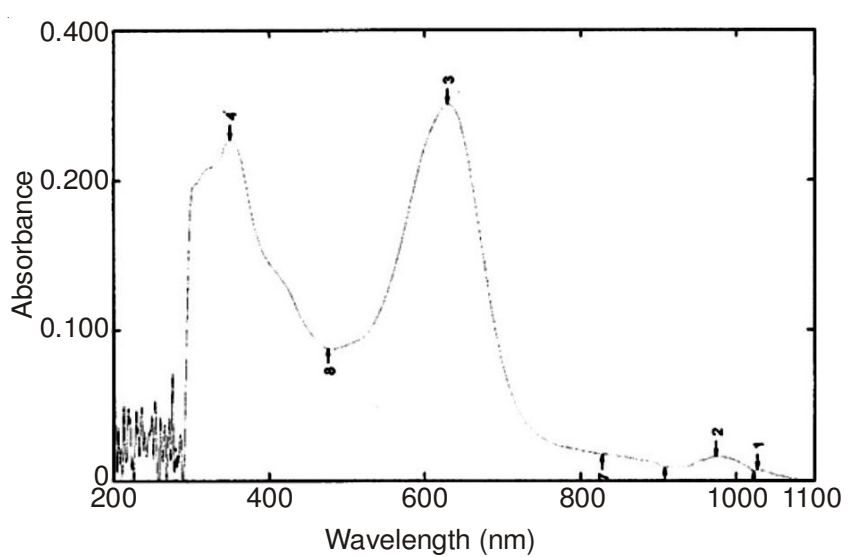

Fig. 10. UV-visible spectrum of Co(III)-Complex

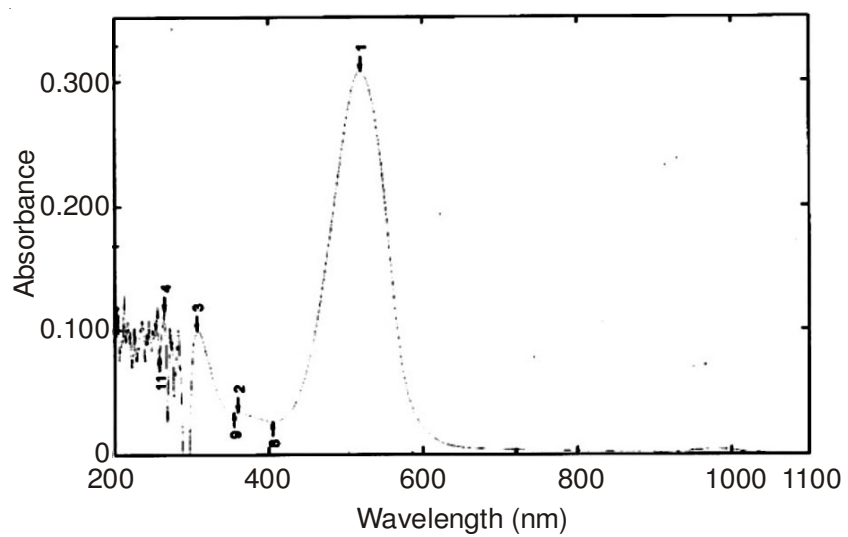

Fig. 11. UV-visible spectrum of Cd(II)-Complex

transition. The magnetic moment value of this complex is 1.64 $\mathrm{BM}$ due to presence of one unpaired electron which may suggests an distorted octahedral structure (Z-out or Z-in) and hybridization $s p^{3} d^{2}\left({ }^{6} \mathrm{t}_{2 \mathrm{~g}}{ }^{3} \mathrm{e}_{\mathrm{g}}\right)^{26,28,33}$.

Zinc(II), cadmium(II) and mercury(II) complexes: The electronic spectra of $\mathrm{Zn}$ (II), Cd(II) and $\mathrm{Hg}$ (II) complexes were recorded in $10^{-3} \mathrm{M}$ ethanolic solution, do not show any $d-d$ transitions because they are saturated with electrons $\left(\mathrm{nd}^{10}\right)$. The absorption bands at $521 \mathrm{~nm}\left(15194 \mathrm{~cm}^{-1}\right), 518 \mathrm{~nm}(15305$ $\left.\mathrm{cm}^{-1}\right)$ and $537 \mathrm{~nm}\left(16622 \mathrm{~cm}^{-1}\right)$ these are assigned to a charge transfer (M $\rightarrow$ L, CT) transation to $\mathrm{Zn}(\mathrm{II}), \mathrm{Cd}(\mathrm{II})$ and $\mathrm{Hg}$ (II) complexes respectively. The magnetic susceptibility show that these metal complexes have diamagnetic moment $\left(\mu_{\mathrm{eff}}=0.00\right)$ $\mathrm{BM}$ and a octahedral geometry and hybridization $s p^{3} d^{2}\left({ }^{6} \mathrm{t}_{2 \mathrm{~g}}\right.$ $\left.{ }^{4} \mathrm{eg}\right)^{31,32}$.

According to there results and discussed through different techniques suggest below the proposed the structural formula of chelate complexes prepared and shown in Fig. 12.

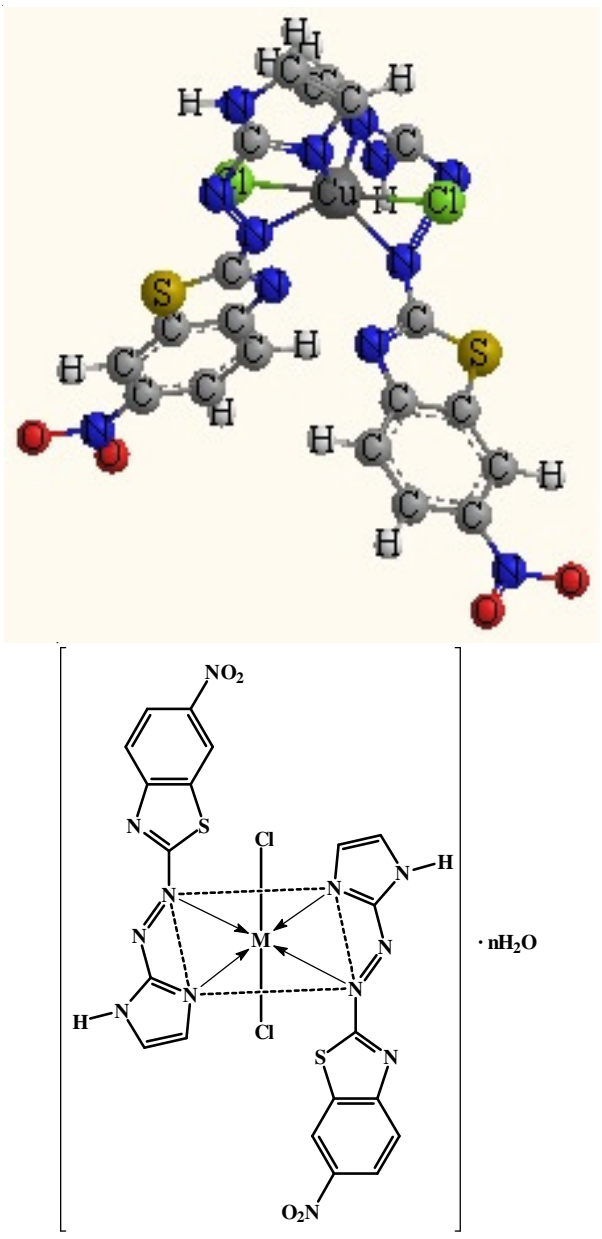

Fig. 12. The proposed chemical formula of chelet complexes when:$\mathrm{M}=\mathrm{Co}(\mathrm{II}), \mathrm{Cu}(\mathrm{II}), \mathrm{Cd}(\mathrm{II})$ and $\mathrm{Hg}(\mathrm{II}) ; \mathrm{n}=1 ; \mathrm{M}=\mathrm{Ni}(\mathrm{II})$ and $\mathrm{Zn}(\mathrm{II})$; $\mathrm{n}=0$ 


\section{Conclusion}

In this paper, we reported the preparation, spectral identification, analytical data and coordination chemistry of azo dye ligand derived from thiazole and imidazole rings (NBTAI) obtained from the coupling reaction of 6-nitro benzothiazole diazonium chloride salt with imidazolee and its metal complexes with $\mathrm{Co}(\mathrm{II}), \mathrm{Ni}(\mathrm{II}), \mathrm{Cu}(\mathrm{II}), \mathrm{Zn}$ (II), $\mathrm{Cd}(\mathrm{II})$ and $\mathrm{Hg}$ (II) metal ions. The azo ligand (NBTAI) behaves as a bidentate chelating agent coordination throught the $\mathrm{N}_{3}$ atom of the imidazolee ring and another nitrogen atom of azo group to form five member metlo-ring. The geometry is proposed for all complexes octahedral sterochemistry. All complex characterized solid metal complexes not effect by air, light and a moisture, suggesting high stability plus high degrees of melting points that gives another evidence of the stability of prepared metal complexes.

\section{REFERENCES}

1. L. Mangsup, S. Siripaisarnpipat and N. Chaichit, J. Anal. Sci., 19, 1345 (2003).

2. D. Dollimore, Anal. Chem., 62, 44R (1990).

3. A. Geronikaki, D. Hadjipavlou-Litina, C. Chatziopoulos and G. Soloupis, Molecules, 8, 472 (2003).

4. W. Stephen, Analyst, 102, 739 (1977).

5. K. Yoshimura, Y. Toshimitsu and S. Ohashi, Talanta, 27, 693 (1980).

6. K.V. Mehta, Int. J. Chem. Technol. Res., 4, 732 (2012).

7. K.J. Al-Adilee, H.K. Dakhil and F.F. Karam, J. AL-Qadisiya Pure Sci, 16, 50 (2011).

8. L.A.A.R. Al-Rubaie and R.J. Mhessn, E-J. Chem., 9, 465 (2012).

9. B.C. Dixit and D.M. Patel, E-J. Chem., 8, 1218 (2011).

10. H.M. Shukla, A.I. Shah, P.J. Shah and D.S. Raj, Der Pharm. Sinica, 1, 165 (2010)

11. P. Wasserscheid and W. Keim, Angew. Chem. Int. Ed., 39, 3772 (2000).

12. Z. Jin, Z. Li and R. Huang, Nat. Prod. Rep., 19, 454 (2002).

13. T. Maier, R. Schmierer, K. Bauer, H. Bieringer and B. Sachse, US Patent 4820335, Chem. Abstr., 89, 19494 (1989).

14. H. Teranishi, K. Takagawa, Y. Arai, K. Wakaki, Y. Sumi and K. Takaya, J. Occup. Health, 44, 60 (2002).
15. Y. Sumi, M.T. Itoh, T. Muraki and T. Suzuki, Histochem. Cell Biol., 106, 223 (1996).

16. M. Šrroki, L. Maric, Z. Štefanac and M.J. Herak, Anal. Chim. Acta, 75, 101 (1975).

17. G. Ramazn, Turk. J. Chem., 36, 1 (2012).

18. M.S. Hosseini and H. Hashemi-Moghaddam, Talanta, 67, 555 (2005).

19. N. Rajesh and M.S. Hari, Spectrochim. Acta A, 70, 1104 (2008).

20 P. Byabartta, S. Pal, T.K. Misra, C. Sinha, F.L. Liao, K. Panneerselvam and T.H. Lu, J. Coord. Chem., 55, 479 (2002).

21. T. Qiu, Y. Shen, J. Hao, J. Zhai, F. Zu, T. Zhang, Y. Zhao, K. Clays and A. Persoons, J. Mater. Sci., 39, 2335 (2004).

22. A.G. Kuhait, M.Sc. Thesis, Universtry of Baghdad, (1984).

23. S.L.M.V. Guser Zhvakin and I.A. Kozherikov, Zh. Anal. Khim., 29, 859 (1971).

24. S. Shibata, M. Furukawa and R. Nakashima, Anal. Chim. Acta, 81, 131 (1976).

25. K.J. Al-Adilee, A. Ghali and A. Hussein, J. Chem. Chem. Eng., 6, 651 (2012).

26. K.J. Al-Adilee, Asian J. Chem., 24, 5597 (2012).

27. A.M. Ali, New J. Chem., 23, 335 (2006).

28. K.J. Al-Adilee, Al-Nahrain Univ. J. Sci., 11, 31 (2008).

29. A. Skooge, D.M. West and F.J. Holler, Fundamentals of Analytical Chemistry, Saunders College Publishing, New York, edn. 5 (1988).

30. H. Irving and R.J.P. Williams, J. Chem. Soc., 3192 (1953).

31. J. Khalid Al-Adilee, J. Chem. Chem. Eng, 6, 1016 (2012).

32. A.M. Ali, New J. Chem., 28, 676 (2007).

33. J. Khalid AL-Adilee, New J. Chem., 28, 585 (2007).

34. M.R. Mahmoud, A.M. Hammam, S.A. El-Gyar and S.A. Ibrahim, Monatsh. Chem., 117, 313 (1986).

35. O. Yamauchi, H. Tanaka and T. Uno, Talanta, 15, 177 (1968).

36. A.Z. El-Sonbati, Transition Metal Chem., 16, 45 (1991).

37. R.G. Denning and J. Thatcher, J. Am. Chem. Soc., 90, 5917 (1986).

38. K.C. Satpfy and H.P. Mishra, Indian. J. Chem., 24A, 612 (1981).

39. S.M. Ben-Saber, A.A. Maihub, S.S. Hudere and M.M. El-Ajaily, Microchem. J., 81, 191 (2005).

40. T. Shimanouchi and I. Nakagawa, Spectrochim. Acta. A, 18, 89 (1962).

41. D. Nicholas, Pergamon Texts in Inorganic Chemistry, Pergamon Press Oxford, edn. 1 (1973).

42. J.D. Lee, Concise Inorganic Chemistry, edn. 5 (2007). 